\title{
Reforming the electric power industry of Russia: matters of concern, challenges, and solutions
}

\author{
Vladimir Golovshchikov ${ }^{1, *}$ \\ ${ }^{1}$ Melentiev Energy Systems Institute of Siberian Branch of the Russian Academy of Sciences, Irkutsk
}

\begin{abstract}
The results of reforms in the Russian electric power industry and the main problems facing the industry that hinder not only its development, but also reduce the efficiency of its operation are presented. The analysis of the current regulatory framework in the electric power industry is provided.It is shown that the ongoing process of digitalization and intellectualization of the electric power industry will fail to attain its full potential unless large-scale technological modernization of the industry is implemented, and both directions should be pursued simultaneously. The wholesale and retail electricity and capacity markets created, as a result of the electricity reform are of low efficiency and call for introducing significant changes. In order to carry out the necessary transformations, some priority measures are proposed to improve the state of affairs in the Russian electric power industry and ensure its prospective development.
\end{abstract}

\section{Introduction}

The problems accumulated over time in the electric power industry of the Russian Federation (RF), caused by the ongoing reform of the industry, for many years keep going the discussion among the academic and engineering community and representatives of authorities at various levels, from federal to municipal [1-10].

At that, both issues of conceptual nature (ways and methods of development of the industry, competition, market relations) and current issues, including equipment health and modernization, informatization, tariff formation, etc. are covered.

At present, the process of digitalization of the country's economy in general and the electric power industry in particular is growing in intensity at the initiative of Russia's top leadership. Various rationales are given to substantiate this direction of development, the most common of which is that "digitalization is a driver of electric power industry development and a step towards introducing artificial intelligence into the industry". In recent years, almost all major events in Russia on the electric power industry have included in their agenda digitalization issues ranging from standardization, to cyber security, to plans for the future. $[11,12]$. The importance of the "digitalization of the electric power industry" is beyond any doubt, as it can have a synergistic effect. With its introduction the possibility of moving away from predictive and preventive maintenance (PPM) to repairs based on the analysis of equipment health, which is enabled by the mature digital fault detection system [12], is considered. This will make it possible to extend the operation of a significant number of power facilities, whose official service life has already expired, by applying "riskoriented management". The national leader in the Russian Federation with respect to digitalization in the power industry is PJSC Rosseti that has developed and has been implementing "The vision statement of digitalization of grids for 2018-2030" with the required amount of investment of 1.3 trillion rubles.

While supporting the digitalization of the electric power industry as a promising direction, it is necessary to pay attention to the existing numerous problems in the industry, many of which should have been solved by now [13]. In order to successfully implement the process of digitalization of the electric power industry and obtain the greatest effect from its results, it is necessary to solve a set of technical, organizational, economic, regulatory, and other issues. First of all, it is required to analyze the goals and objectives of the reform of the industry, assess its results, and identify the most negative aspects. On the basis of this analysis one is to formulate (or notably adjust the existing approaches) the Vision statement of the electric power industry operation and development, establish an appropriate model, and, on their basis, develop an appropriate strategy and specific plans for its implementation, which will organically incorporate the digitalization of the industry.

The prime movers behind the reform of the electric power industry, who were part of the Russian leadership in the late 1990 s and early 2000 s, were known to rely on poorly studied international experience of similar reforms and believed that the establishment of competitive relations in the industry will ensure its efficient development. Conceptual and legislative support for the electric power industry reform process at

\footnotetext{
Corresponding author: vladgo@,isem.irk.ru
} 
the first stage was provided by the following documents: 1) Vision statement "Strategies of RAO UES of Russia" (Vision statement "5+5" (1998-2003 and 2003-2008). The main goals of the " $5+5 "$ vision statement were aimed at improving the financial condition of the then unified electric power holding company RAO UES of Russia. These objectives had largely been met by 2008 . Technological development issues were unfortunately sidelined. Perhaps this was due to the fact that their urgency was significantly reduced as a result of a decrease in consumer demand caused by the slump in industrial production. However, this only pushed back the need for technical re-equipment of the electric power system and aggravated the situation under growing demand for electricity. The next stage of reforming the electric power industry was regulated by such documents as Resolution of the Government of the Russian Federation No. 526-p "On reforming the electric power industry" (July 2001); 3) Federal Law No. 35-FZ "On the electric power industry" (2003). They set the goals, objectives, and directions of the reform, while the assessment of the consequences of these objectives was again not carried out. As a result, despite certain advances, a number of anticipated results were not achieved.

1. Efficient competitive markets for electricity and heat have been created on neither the production nor consumption sides. Major energy companies and shareholders have enjoyed significant preferential advantages in these markets.

2. Cross-subsidization (between energy consumer groups and territories such as "Far East", "Crimea", etc.) has been retained. There are more and more examples of "the manual override" based on instructions from "the very top" in various areas of life in the country.

3. The balance of interests of all players of energy markets is not ensured. The primary benefits were secured by generating and power supply companies. At the same time, CHP plants operating in two markets, those of electricity and heat, found themselves at a disadvantage. The peculiarities of their operation, as well as those of heat supply in general, were ignored during the reform.

4. Efficient fuel markets for power plants have not been formed. Gazprom is in possession of an absolute monopoly in the gas market. The situation in the coal market is slightly better, but the monopolistic pressure is felt there as well.

5. Tariffs for electricity and heat (capacity) for end consumers continue to grow, with rates generally exceeding the inflation rate.

6. Proclaimed measures to reduce costs of generating, grid, and power supply companies fail to work as the basis for tariff reduction.

7. The development of the electric power industry is due to the growth of tariffs for consumers, while market mechanisms (bonds, shares, etc.) are practically not employed.

8. Coordination and efficient management of most of the country's power sector was lost after the reorganization of the RAO UES holding company. The fragmentation of the industry into many companies of different sizes and lack of competition has led to inefficient operation and development of the electric power industry. The energy industry is gradually losing its infrastructure functions, becoming a mere supplement of some industries and even that of some major consumers.

9. The Ministry of Energy of the Russian Federation has failed to develop into a full-fledged hub of expertise and governance of the electric power industry (the oil and gas industry are at the top of the Ministry's agenda).

10. The aging process of the main energy facilities (at least 60 percent on average) shows no signs of abatement and outpaces the ongoing efforts to modernize and develop the energy facilities, despite the introduction of such arrangements as Capacity Delivery Agreements (CDA) and CDA+ (for the modernization of heat power industry facilities), RAB regulation (Fair ROI), the current tariff policy, etc.

11. The existing and constantly growing legal and regulatory framework governing relations in the electric power industry proves extremely complex and oftentimes inconsistent.

12. The law enforcement practice of some important legal acts (e.g. Federal Law No. 261-FZ "On Increasing Energy Efficiency", Decree of the Government of the Russian Federation No. 511-r, etc.) is unsatisfactory.

13. Constructive feedback given by the academic and engineering community on how to improve the situation in the electric power sector is received and heard by official authorities, but decisions are either not made or implemented too slowly.

The negative results of the electric power industry reform (with some of them listed above) that continues in the sluggish fashion to this day, are due to the fact that the decisions made were not thought out well enough, with the specifics of the Russian electric power industry and many years of previous experience of successful operation of the electric power industry ignored. This could not but have a negative impact on results and the achievement of targets.

Among the priority measures contributing to the overcoming of negative processes and the consistent transition of the electric power industry to a new innovative path of its development, the following should be highlighted:

- Analysis and evaluation of the results of the electric power industry reform, including all issues discussed within the framework of the discussion held by the academic and engineering community [1, 2, 14-16].

- Creation of a working group to summarize the results of the reform and develop practical mandatory measures to eliminate its negative consequences $[1,2]$.

At the same time, it is necessary to start implementing priority measures:

1. Ensuring that all power plants can enter the wholesale and retail energy and capacity markets.

2. Consolidation of territorial (distribution) power grid companies on the basis of the most efficient of them, which is a mandatory requirement as per Decree of the Government of the Russian Federation № 511-r (dated April 3, 2013).

3. Providing power grid companies with an opportunity to carry out power sales activities based on economic 
feasibility, as there is no real competition among power supply companies for consumers.

4. Consolidation of retail electricity and heat markets into the "Unified retail electricity and capacity market" that ensures a positive effect for all players of this market [17].

5. Gradual transformation of the wholesale electricity and capacity market into a balancing market.

6. Formation of differentiated tariffs in the integrated power grid for services related to electric power transmission via the grids. Such tariffs should factor in the real costs of electricity transmission to specific consumers.

7. Ensuring unconditional financial responsibility for quality and reliability of power supply.

8. Embarking on the most up-to-date technological directions in the development of the electric power industry, including "digital technology", "smart power systems", "artificial intelligence", etc., the implementation of which is reasonable to launch in the form of pilot projects with the analysis of the results thus obtained and further development of the projects.

\section{Conclusion}

The main goals and tasks of reforming the Russian electric power industry, formulated more than two decades ago, have not been achieved. Efficient competitive electricity and capacity markets have been created on neither the production nor consumption sides. Hopes for attracting capital have not been fulfilled either as all development is carried out at the expense of consumers.

For the efficient development of the industry, it is necessary to analyze thoroughly the results of the reform. Based on the analysis and taking into account the already available constructive feedback, one is to develop a new vision statement for the development of the Russian electric power industry, while factoring in both the internal situation and external trends, including challenges and threats. The new vision statement should provide guidelines for the development of the strategy of the Russian electric power industry and specific plans for its implementation. Some important and urgent directions can be implemented in the short term (a year or two) and medium term (three to five years).

\section{Acknowledgements}

This work is carried out as part of the fundamental research program III.17.4.4 of the Siberian Branch of the Russian Academy of Sciences, scientific project № AAAA-A17-117030310449-7, and with the support of the Russian Foundation for Basic Research, grant № 019-010-00183.

\section{References}

1. G.P. Kutovoy. In need of a new paradigm (or architectonics) of economic relations in the electric power industry. Energetik, No. 2 (2016), pp. 8-13. (In Russian)

2. G.P. Kutovoy. On the need to continue reforms in the electric power industry. Energoekspert, No. 3 (2019), pp. 18-25. (In Russian)

3. V.O. Golovshchikov. Issues of reforming the electric power industry in Russia and their impact on market relations. Energorynok, No. 5 (2016), pp. 30-35. (In Russian)

4. V.A. Stennikov. On reforming heat supply in Russia. Energosberezhenie, No. 5 (2014), pp. 63-66. (In Russian)

5. V.A. Stennikov. On reforming heat supply in Russia (cont'd). Energosberezhenie, No. 6 (2014), pp. 62-67. (In Russian)

6. V.O. Golovshchikov. The issue of electric power quality under the conditions of market relations in Russia. Energorynok, No. 6 (2016), pp. 26-30. (In Russian)

7. L.S. Belyaev. Issues of the electric power market. Novosibirsk: Nauka, 2009. - 296 p.

8. I.S. Kozhukhovsky. Key results of the electric power sector reform and new challenges. Regional'naya energetika i energosberezhenie. No. 4 (2018), pp. 8-15. (In Russian)

9. Yu.A. Zhilkina. Issues of reforming the electric power industry in Russia. Energetik, No. 1 (2020), pp. 29-32. (In Russian)

10. V.A. Stennikov, V.O. Golovshchikov. Current issues and ways of transformation of the Russian electric power industry. Energetik, . No. 6 (2020), pp. 3-9. (In Russian)

11. "The energy system of the future must be built by new generation leaders». http://eepir.ru/news/item/9771-energ-budushegostroyat-lidderi.html (Accessed 10.11.2018) (in Russian)

12. Reliability of power supply is our priority task. An interview with A.V. Cherezov. Elektroenergiya: Peredacha i raspredelenie. No. 3 (2019), pp. 6-13. (In Russian)

13. V.O. Golovshchikov. Is the Russian electric power industry ready for the transition to a new technological platform based on mass digitalization? Energetik, No. 11 (2018), pp. 3-6. (In Russian)

14. V.A. Stennikov, S.I. Palamarchuk, V.O. Golovshchikov. Creating effective retail electricity and heat markets is the most important task of the domestic electric power industry. Energetik, No. 2 (2018), pp. 3-6. (In Russian)

15. V.V. Kudryavy. Ways to improve efficiency of the energy industry. Open seminar "Economic problems of the energy sector industries" (presentation and panel discussion). June 28, 2016. - Moscow: Publishing house of the Institute of Economic Forecasting, RAS. 2016, pp. 1-20. (In Russian) 
https://ecfor.ru/publication/energeticheskij-seminar17-puti-povysheniya-effektivnosti-energetiki/

16. V.V. Kuzmin. On approaches to development of the Russian electric power market. Energetik, No. 6 (2019), pp. 9-14. (In Russian)

17. V.A. Stennikov, V.O. Golovshchikov. Electricity and heat retail market: challenges and development prospects. Energetik, No. 6. (2019), pp. 3-9. (In Russian) 